\title{
PENGEMBANGAN INSTRUMEN UNTUK MENGUKUR BERPIKIR KONSERVASI ANAK USIA 5-6 TAHUN
}

\author{
Resna Rosmayanti ${ }^{1}$, Edi Hendri Mulyana ${ }^{2}$, Elan $^{3}$ \\ ${ }^{1}$ Program Studi PGPAUD UPI Kampus Tasikmalaya \\ ${ }^{2}$ Program Studi PGPAUD UPI Kampus Tasikmalaya \\ ${ }^{3}$ Program Studi PGPAUD UPI Kampus Tasikmalaya
}

Email: edihm@upi.edu

(Received: Nopember 2019; Accepted: Nopember 2019; Published: Desember 2019)

\begin{abstract}
This study aims to determine the ability of children on conservation thinking. The type of research that is used is Design Based Research conducted by Face To Face with the subject of the researcher. The research model is Reeves model, where the research was conducted in two trials. Subjects in this study were five children aged 56 years. Instrument used is the observation sheet (check list) and documentation. Then the research procedure consists of 4 stages namely 1) identification and analysis of the problem, 2) product design development, 3) product testing, and 4) product reflection
\end{abstract}

Keywords: Conservation Thinking, Children 5-6 Years, Desain Based Research

\begin{abstract}
ABSTRAK
Penelitian ini bertujuan untuk mengetahui kemampuan anak pada berpikir konservasi. Jenis penelitian yang di gunakan yaitu Desain Based Research yang dilakukan secara Face To Face dengan subjek peneliti. Model penelitiannya yaitu model Reeves, dimana penelitian ini dilaksanakan dalam dua kali uji coba. Subjek dalam penelitian ini adalah lima orang anak yang berusia 5-6 tahun . Instrument yang digunakan yaitu lembar observasi (check list) dan dokumentasi. Kemudian prosedur penelitiannya terdiri dari 4 tahapan yaitu 1) identifikasi dan analisis masalah, 2) pengembangan desain produk, 3) uji coba produk, dan 4) refleksi produk
\end{abstract}

Keywords: Berpikir Konservasi, Anak Usia 5-6 Tahun, Desain Based Research (DBR) 


\section{PENDAHULUAN}

Undang-undang nomor 20 tahun 2003 tentang Sistem Pendidikan Nasional Berkaitan dengan Pendidikan Anak Usia Dini pada Bab I pasal 1 Ayat 14 menegaskan bahwa

"Pendidikan anak usia dini adalah suatu upaya pembinaan yang ditujukan kepada anak sejak lahir sampai dengan usia enam tahun yang dilakukan melalui pemberian rangsangan pendidikan untuk membantu pertumbuhan dan perkembangan jasmani dan rohani agar anak memiliki kesiapan dalam memasuki pendidikan lebih lanjut." (Sujiono, 2013, hlm. 6). Dalam paparan tersebut dapat dikatakan bahwa pendidikan anak usia dini merupakan pendidikan yang ditujukan pada anak dari sejak lahir secara informal yaitu dari keluarga, sampai dengan usia 6 tahun yang dilakukan melalui pemberian rangsangan pendidikan agar anak siap dalam pendidikan ke jenjang yang lebih tinggi.

Pendidikan bagi anak usia dini adalah pemberian upaya untuk menstimulasi, membimbing, mengasuh dan pemberian kegiatan pembelajaran yang akan menghasilkan kemampuan dan keterampilan anak. (Sujiono, 2013, hlm. 7). Pendidikan terutama bagi anak usia dini yaitu dari sejak lahir sampai usia 6 tahun, dilakukan dengan pemberian upaya untuk menstimulasi, membimbing, mengasuh, dan memberikan kegiatan yang dapat meningkatkan kemampuan dan keterampilan pada diri anak. Dengan demikian dapat dikatakan bahwa pendidikan anak usia dini merupakan suatu pendidikan sejak lahir sampai usia enam tahun yang dilakukan melalui pemberian ransangan agar anak dapat tumbuh dan berkembang untuk kedepannya. Pada pendidikan anak usia dini dibagi menjadi 3 bagian yaitu 1). Pendidikan informal, berbentuk pendidikan keluarga atau pendidikan yang diselenggarakan oleh pendidikan, 2). Pendidikan Formal, berbentuk TK, RA, atau bentuk lain yang sederajat. 3).
Pendidikan Nonformal berbentuk KB, TPA atau bentuk lain yang sederajat. (Dr. Yuliani, 2013, hlm.16). Pendidikan anak usia dini merupakan upaya untuk mengoptimalkan perkembangan anak usia dini.

Anak usia dini adalah sosok individu yang menjalani suatu proses perkembangan dengan pesat dan fundamental bagi kehidupan selanjutnya (Sujiono, 2013, hlm. 6). Pada masa anak usia dini yaitu 0-6 tahun, dimana pada masa ini perkembangan yang ada dalam dirinya berkembangan sangat pesat, maka pada saat masa ini anak harus di beri stimulus, rangsangan juga perkembangan yang sesuai agar nantinya berpengaruh bagi kehidupan selanjutnya. Sedangkan Menurut Imam AlGazali (dalam Dr. Hj. Ihsana El-Khuluqo, M.Pd. 2015, hlm. 40) "anak merupakan amanah Allah kepada orang tuanya, hatinya masih suci, siap menerima segala bentuk ajaran dan penanaman nilai sebagaimana kertas kosong yang masih putih." Jadi pada saat masih usia dini apabila orangtua/pendidik bisa memberikan suri tauladan yang baik dan perkembangan yang tepat bagi anak, maka anak tersebut nantinya akan menjalani masa usia dini dengan sesuai. Dari pembahasan tersebut maka anak usia dini adalah sosok individu yang mempunyai karakteristik tertentu yang khas dan harus dikembangkan untuk masa depannya nanti. Pada masa anak usia dini merupakan masa yang sangat penting atau disebut dengan golden age dimana pada masa ini hanya terjadi satu kali dan tidak dapat diulang. Agar pada masa anak usia dini dapat optimal maka orangtua atau pendidik harus mengembangan perkembangan intelektual yang ada pada diri anak

Menurut Catron dan Allen (dalam Sujono, 2013, hlm. 62) terdapat 6 aspek perkembangan anak usia dini yaitu 1). Kesadaran personal, 2). Pengembangan emosi, 3). Membangun sosialisasi, 4). Pengembangan komunikasi, 5). Pengembangan kognitif, 6). Pengembangan kemampuan motorik. Salah satu yang akan dikembangkan yaitu pada perkembangan kognitif anak. Desmita (2013, hlm. 130) menjelaskan bahwa perkembangan kognitif 
pada masa awal anak-anak dinamakan tahap pra-operasional (praoperational stage), yang berlangsung dari usia 2-7 tahun. Salah satu aspek perkembangan pada anak yaitu perkembangan kognitif Kognitif dapat diartikan dengan pemahaman tentang pengetahuan yang didapat oleh anak. Perkembangan kognitif Pada usia pra sekolah dasar mencangkup usia 2-7 tahun, masuk dalam tahap praoperasional. Didalam tahap praoperasional ada sub tahap intuitif.

Nobuki W (Dalam journal of educational and Developmental psychology, 2017, hlm.1) menurut jean piaget, anak-anak berusia antara 4-7 tahun berada dibawah sub-tahap intuitif pada tahap praoperasional. Selanjutnya Olivia S (2015, hlm. 49) Menjelaskan bahwa sub tahap pemikiran intuitif, yang terjadi pada rentang usia 4-7 tahun, disini anak-anak mulai berlatih mengelompokkan sesuatu, bisa melalui latihan-latihan sederhana seperti mengelompokkan benda berdasarkan warna atau ukurannya, intinya diusia ini mereka mulai belajar mengklasifikasikan. Dalam tahap pemikiran intuitif anak sudah mulain mengelompokan sesuatu berdasarkan warna, ukurannya, pada masa ini anak sudah mengetahui persamaan dan perbedaan pada suatu objek.

Sujiono (2013, hlm.80) menjelaskan bahwa permulaan pada tahap pra-operasional ditandai oleh adanya kemampuan dalam menghadirkan objek dan pengetahuan, Dengan demikian pada usia pra-operasional ada yang dinamakan sub tahap intuitif dimana pada tahap ini anak mulai berlatih mengelompokkan sesuatu, juga kemampuan dalam menghadirkan objek dan pengetahuan. Dalam sub tahap intuitif yang terjadi pada anak usia 4-7 tahun dimana pada tahap ini anak mulai berlatih mengelompokkan sesuatu melalui latihan-latihan sederhana, mengklasifikasikan, menghadirkan objek dan pengetahuan juga menghadirkan konservasi. Konservasi digambarkan sebagai pengetahuan mengenai nomor, jumlah, massa, panjang, berat, dan volume dari objek yang tidak berubah apabila secara fisik.(Sujiono, 2013, hlm.80). Perkembangan kecerdasan berpikir konservasi merupakan perkembangan yang amat penting diusia anak usia dini yang akan melanjutkan pendidikan dasar karena kelak akan menentukan perkembangan kecerdasan anak. Masa perkembangan yang sangat menentukan adalah ketika anak berada pada usia masuk sekolah formal (6-7 tahun). Masa ini dikenal dengan masa konservasi, artinya pada masa ini merupakan usia menentukan, yaitu masa peralihan atau perpindahan dari berpikir pra operasional ke operasional konkrit. Penguasaan konservasi merupakan hal yang penting untuk membekali siswa supaya mampu/cakap dalam belajar (Carin \& Sund, 1989, hlm. 34). Oleh karena itu dalam pengalaman belajar, siswa perlu diberi tugastugas (task) yang menyangkut konservasi supaya dapat meningkatkan kemampuan siswa dalam memecahkan masalah konservasi juga untuk membekali siswa supaya cakap dalam belajar.

Salah satu contoh kecerdasan dalam berpikir konservasi yang baik adalah ketika anak dapat mengetahui tentang sesuatu objek yang akan tetap sama walaupun di ubah bentuknya. Kenyataan dilapangan dalam berpikir konservasi tidak sedikit pendidik/orangtua yang kurang mengukur perkembangan berpikir konservasi. Berpikir konservasi sangat penting dilakukan karena nantinya anak dapat cakap dalam belajar. Anak dasarnya memiliki kemampuan untuk membangun dan mengkreasi pengetahuan sendiri, sehingga sangat penting bagi anak untuk terlibat langsung dalam proses belajar. Piaget (dalam Sujiono, 2013, hlm. 121) anak pada masa praoperasional belajar melalui active learning, metode yang digunakan adalah dengan memberikan pertanyaan pada anak dan membiarkan berpikir/bertanya pada diri sendiri, sehingga hasil belajar yang didapatkan merupakan kunstruksi anak tersebut. Maka dari itu agar perkembangan berpikir konservasi anak berkembang, perlu dilakukannya sesuatu untuk mengukur berpikir konservasinya. Ini dapat didapat melalui pengalaman belajar dengan cara melakukan percobaan dengan objek nyata.

Berdasarkan beberapa hal yang telah dipaparkan, peneliti tertarik untuk merancang 
suatu penelitian untuk mengukur berpikir konservasi dengan menggunakan buku panduan sebagai pedoman untuk alat ukur. Oleh karena itu, peneliti akan melakukan penelitian dengan judul "pengembangan instrumen untuk mengukur berpikir konservasi anak usia 5-6 tahun", dengan harapan dapat membantu menyajikan pedoman untuk alat ukur bagi pendidik/ orangtua terutama untuk mengembangkan berpikir konservasi anak.

\subsection{Rumusan Masalah Penelitian}

Dari latar belakang diatas maka rumusan masalah penelitiannya :

1.2.1 Bagaimana dasar kebutuhan pengembangan instrumen untuk mengukur berpikir konservasi anak usia 5-6 tahun?

1.2.2 Bagaimana Rancangan pengembangan instrumen untuk mengukur berpikir konservasi anak usia 5-6 tahun?

1.2.3 Bagaimana hasil uji coba dan revisi pengembangan instrumen untuk mengukur berpikir konservasi anak usia 5-6 tahun?

1.2.4 Bagaimana hasil akhir pengembangan instrumen untuk mengukur berpikir konservasi anak usia 5-6 tahun?

\subsection{Tujuan Penelitian}

Berdasarkan permasalaham yang telah dirumuskan, peneliti menyusun tujuan penelitian sebagai berikut:

1.3.1 Menganalisis kondisi dan potensi pengembangan instrumen untuk mengukur berpikir konservasi anak usia 5-6 tahun.

1.3.2 Mengevaluasi hasil uji coba pengembangan instrumen untuk mengukur berpikir konservasi anak usia 5-6 tahun.

1.3.3 Menghasilkan produk pengembangan berupa buku panduan berpikir konservasi untuk mengukur perkembangan berpikir konservasi pada anak usia 5-6 tahun.

\subsection{Manfaat Penelitian}

Penelitian ini diharapkan dapat memberikan banyak manfaat. Manfaat tersebut dijelaskan dibawah ini.

\subsubsection{Manfaat Teoritis}

Penelitian ini diharapkan dapat bermanfaat dalam sumbangan ide terhadap pengembangan instrumen untuk mengukur berpikir konservasi sehingga dapat memfasilitasi perkembangan anak usia 5-6 tahun.

\subsubsection{Manfaat Praktis}

1) Bagi Anak

a. Membantu anak untuk mengembangkan kemampuan anak dalam berpikir konservasi.

b. Membantu anak untuk memiliki kecakapan dalam belajar untuk melanjutkan ke jenjang yang lebih tinggi.

2) Bagi Guru

a. Memberikan sumbangan ide untuk mengukur berpikir konservasi anak usia 5-6 tahun.

b. Mempermudah guru agar bisa mengukur berpikir konservasi anak usia 5-6 tahun, sehingga guru bisa melakukannya sesuai yang ada di buku panduan.

3) Bagi Sekolah

Penelitian ini diharapkan dapat bermanfaat untuk menyumbangkan ide dalam menerapkan pengembangan instrumen untuk mengukur berpikir konservasi anak usia 5-6 tahun.

4) Bagi Peneliti

Penelitian ini bermanfaat untuk mengembangkan keterampilan, menambah pengalaman, pengetahuan baru dan wawasan, serta mengasah diri untuk dapat menyumbangkan ide

\section{TINJAUAN PUSTAKA}

\subsection{Perkembangan Kognitif}

Menurut Syamsu Yusuf (2008, hlm. 15) perkembangan dapat diartikan sebagai "perubahan yang progresif dan kontinyu (berkesinambungan) dalam diri individu dari mulai lahir sampai mati”. Dalam pendapat tersebut perkembangan merupakan suatu perubahan yang tidak akan hilang, perubahan ini bersifat bertahap dan berkesinambungan dari dalam diri seseorang mulai dari sejak dia lahir sampai mati. Sedangkan menurut Reni Akbar Hawadi 2001 (dalam Desmita 2013, hlm. 4). "perkembangan secara luas menunjuk pada keseluruhan proses perubahan dari potensi yang dimiliki individu dan tampil dalam kualitas kemampuan, sifat dan ciri-ciri 
yang baru. Dalam penjelasan menurut Reni, perkembangan merujuk pada perubahan dari dalam diri salah satunya berupa potensi yang dimilikinya.

Menurut F.J. Monks, dkk., 2001 (dalam Desmita 2013, hlm 4) pengertian perkembangan merujuk pada "suatu proses kearah yang lebih sempurna dan tidak dapat diulang kembali. Perkembangan menunjuk pada perubahan yang bersifat tetap dan tidak dapat diputar kembali." Perkembangan juga dapat diartikan sebagai “ proses yang kekal dan tetap yang menuju kearah suatu organisasi pada tingkat integrasi yang lebih tinggi, berdasarkan pertumbuhan, kematangan, dan belajar." Perkembangan hanya terjadi sekali seumur hidup tidak bisa diulang kembali. Maka dari itu agar perkembangan merupakan sesuatu yang amat penting untuk kedepannya.

Dari devinisi diatas dapat dikatakan bahwa perkembangan merupakan sesuatu yang tidak dapat diukur dengan alat pengukur, karena perkembangan merupakan perubahan yang ada dalam diri seseorang. Perkembangan ada didalam diri seseorang yang meliputi kecerdasan, kematangan, juga perubahan potensi yang dimilikinya dari sejak lahir.

Desmita (2013, hlm. 103) menyatakan "perkembangan kognitif adalah salah satu aspek perkembangan manusia yang berkaitan dengan pengertian (pengetahuan), yaitu semua proses psikologis yang berkaitan dengan bagaimana individu mempelajari dan memikirkan lingkungannya." Sedangkan dalam Dictionary of psychology karya chaplin (dalam desmita 2013, hal 103) kognitif adalah konsep umum yang mencangkup semua bentuk pengenal, termasuk didalamnya mengamati, melihat, memperhatikan, memberikan, menyangka membayangkan, memperkirakan, menduga dan menilai. Perkembangan kognitif merupakan suatu aspek perkembangan manusia yang berkaitan dengan pengetahuannya bagaimana dia dapat memecahkan masalah ataupun memungkinkan seseorang memperoleh pengetahuan baru dari apa yang dilihatnya. Sementara Siti Partini Suwardiman (2003:1) membatasi pengertian kemampuan kognitif pada anak usia dini, yakni daya atau kemampuan anak untuk berpikir dan mengamati, melihat hubunganhubungan, kegiatan yang mengakibatkan seorang anak memperoleh pengetahuan baru yang banyak di dukung oleh kemampuan bertanya. Dengan demikian dapat diketahui bahwa perkembangan kognitif menunjukkan perkembangan dari anak berpikir. Kemampuan anak untuk mengkoordinasikan berbagai cara untuk menyelesaikan berbagai masalah dapat dipergunakan sebagai tolak ukur pertumbuhan kecerdasan. Dalam kemampuan kognitif, anak berkemampuan berpikir melalui pengamatan, menggolongkan, menghubungkan, menguraikan.

\section{Tahap Perkembangan Kognitif Anak}

Menurut Jean Piaget (dalam Santrock, 2007, hlm. 246) perkembangan anak usia dini dibagi menjadi 4 tahapan yaitu :

a. Tahap Sensorimotor (0-2 tahun)

Bayi memperoleh pengetahuan tentang dunia dan tindakan-tindakan fisik yang mereka lakukan. Bayi mengkoordinasikan pengalaman-pengalaman sensorik dengan tindakan-tindakan fisik. Seorang bayi berkembang dari tindakan refleksif, instingtif pada saat kelahiran hingga berkembangannya pemikiran simbolik awal pada akhir tahap ini.

b. Tahap Praoperasional (2-7 tahun)

Anak mulai menggunakan gambarangambaran mental untuk memahami dunianya. Pemikiran-pemikiran simbolik, yang direfleksikan dalam penggunaan kata-kata dan gambar-gambar mulai digunakan dalam penggambaran mental, yang melampaui hubungan informasi sensorik dengan tindakan fisik. Akan tetapi, ada beberapa hambatan dalam pemikiran anak pada tahapini, seperti egosentris dan sentralisasi. Permulaan dari tahap ini ditandai oleh adanya kemampuan dalam menghadirkan objek dan pengetahuan melalui imitasi, konservasi, permainan simbolis, menggambar, gambaran mental, dan bahasa lisan.

c. Tahap Operasional Konkret (7-11 tahun) 
Anak mampu berpikir logis mengenai kejadian-kejadian konkret, memahami konsep percakapan, mengorganisasikan objek menjadi kelas-kelas hierarki (klasifikasi) dan menempatkan objek-objek dalam urutan yang teratur (serialisasi)

d. Tahap Operasional Formal (11 tahun ke atas)

Pada tahap operasional formal ditandai dengan Remaja berpikir secara lebih abstrak, idealis, dan logis.

Berdasarkan tahap tersebut usia 5-6 tahun berada dalam tahap praoperasional, dimana permulaan pada tahap ini ditandai dengan adanya kemampuan dalam menghadirkan objek, kemampuan melalui imitasi dan juga dan juga adanya konservasi. Untuk tahapan tersebut sebaiknya anak dapat mencapai tahap perkembangannya. Dalam tahap ini perkembangan anak sebaiknya dapat berkembang sesuai usianya, agar nanti anak dapat mengikuti tahap-tahap selanjutnya dengan menyesuaikan perkembangan yang akan dicapainya.

2. Karakteristik perkembangan kognitif pada anak usia 5-6 tahun

Peraturan Menteri Pendidikan dan kebudayaan Republik Indonesia Nomor 137 Tahun 2014 lampiran 1 tentang Standar Isi Tingkat Pencapaian Perkembangan Anak untuk anak usia 5-6 tahun dalam lingkup perkembangan kognitif (berpikir logis), diantaranya adalah sebagai berikut :

a. Mengenal perbedaan berdasarkan ukuran: "lebih dari"; "kurang dari"; dan

"paling/ter"

b. Menunjukkan inisiatif dalam memilih tema permainan (seperti: "ayo kita bermain purapura seperti burung")

c. Menyusun perencanaan kegiatan yang akan dilakukan

d. Mengenal sebab-akibat tentang lingkungannya (angin bertiup menyebabkan daun bergerak, air dapat menyebabkan sesuatu menjadi basah)

e. Mengklasifikasikan benda berdasarkan warna, bentuk, dan ukuran (3 variasi) f. Mengklasifikasikan benda yang lebih banyak ke dalam kelompok yang sama atau kelompok yang sejenis, atau kelompokberpasangan yang lebih dari 2 variasi

\section{g. Mengenal pola ABCD-ABCD}

h. Mengurutkan benda berdasarkan ukuran dari paling kecil ke paling besar atau sebaliknya.

Sementara itu, menurut Caplan (dalam M.Rahmli, 2015:196) menjabarkan kemampuan kognitif anak usia 6 tahun adalah sebagai berikut :

1. Suka mempraktekkan kemampuan intelektual. Misalnya, setelah anak mendapat penjelasan dari guru di sekolah bawah sampah di buang pada tempat sampah, maka anak akan memprakrekkan pengetahuan tersebut sampau di kehidupan nyata mereka.

2. Memahami beberapa kata-kata ukuran dan kuantitas, seperti separuh, semua, besa-kecil, lebih banyak-lebih sedikit, serta tinggi-pendek

3. Mulai melihat hubungan kapasitas wadah yang berbeda bentuk

4. Dapat menggali huruf-huruf besar namun tertentu.

5. Dapat memisah-misahkan benda berdasarkan ukuran, warna, bentuk, tekstur dan lain-lainnya.

\subsubsection{Berpikir konservasi}

Kemampuan berpikir konservasi adalah kemampuan anak untuk berhubungan dengan sejumlah aspek yang berbeda secara serempak (Johnson \& Medinnus, 1974). Dalam pemaparan tersebut kemampuan berpikir konservasi merupakan suatu kemampuan yang dimiliki oleh anak pada saat dihadapkan oleh beberapa aspek yang sedang dihadapinya dan aspek tersebut berbeda semuanya. Dalam Desmita (2006) konservasi yaitu kemampuan untuk memahami sifat-sifat atau aspek-aspek tertentu dari suatu objek atau stimulus tetapi tidak berubah ketika aspek aspek lain mengalami perubahan. Jadi konservasi merupakan suatu kemampuan dalam diri seseorang untuk mengetahui bahwa sifat atau aspek suatu benda apabila di lakukan 
perubahan maka sifat atau aspek pada objek tersebut tidak akan berubah dan akan sama seperti semulanya.

Dr. Yuliani Nurani (2013:80) konservasi digambarkan sebagai pengetahuan mengenai nomor, jumlah, massa, panjang, berat, dan volume dari objek yang tidak berubah apabila secara fisik. Dalam hal ini konservasi mempunyai beberapa karakteristik yang terdapat pada pengetahuan mengenai jumlah dimana pada konservasi jumlah dapat dijelaskan dengan jumlah suatu objek akan tetap sama walaupun objek tersebut posisinya dengan semulanya. Ataupun pada konservasi massa dapat dijelaskan dengan banyaknya suatu objek akan tetap sama walaupun objek tersebut bentuknya berubah tidak seperti aslinya. Pada konservasi panjang pun walaupun panjang dari suatu objek dibengkokan maka objek tersebut panjangnya tetap sama dengan semulanya namun yang hanya berubah yaitu wujudnya. Konservasi berkenaan dengan pengertian, bahwa sifat-sifat suatu objek tetap sama meskipun terjadi transformasi-transformasi pada objek tersebut. Selanjutnya Piaget menyatakan bahwa konservasi merupakan prasarat bagi segala aktivitas intelektual atau untuk berpikir kuantitatif dan matematis (Monk, 2002). Dalam hal ini berpikir konservasi merupakan sesuatu yang penting yang harus dikembangkan dimana berpikir konservasi ini merupakan salah satu hal yang harus dilakukan karena berpikir konservasi ini dapat mengembangkan kemampuan untuk berpikir matematis.

Dari pembahasan diatas dapat disimpulkan bahwa konservasi adalah suatu kemampuan anak untuk mengetahui bahwa selama suatu obyek (benda) tidak ditambah atau dikurangi, maka karakteristik-karakteristik tertentu dari obyek (benda) itu tidak berubah (tetap sama) meskipun pada obyek (benda) itu telah dilakukan perubahan dalam bentuk aslinya. Salah satu hal yang penting dalam berpikir konservasi yaitu dapat mengembangkan kecakapan anak, segala aktivitas intelektual (yang ada didalam diri), mengembangkan berpikir kuantitatif dan matematis.

\section{Tahap berpikir konservasi}

Menurut Carin \& Sund (1989: 34) terdapat tujuh jenis konservasi yang berkembang di dalam struktur kognitif anak pada tahap operasional konkrit. Ketujuh jenis konservasi adalah sebagai berikut :

a. Konservasi jumlah, pada saat anak rata-rata berusia sekitar 6,5 - 7 tahun; "Banyaknya elemen suatu obyek adalah tetap meskipun tempatnya diubah". Jumlah kelereng pada mangkuk tidak akan berubah jumlahnya meskipun dipindahkan ke dalam gelas.

b. Konservasi panjang, pada saat anak rata-rata berusia sekitar 6 - 7 tahun; "Panjang suatu obyek akan tetap sama meskipun bentuknya diubah". Seekor semut akan menempuh jarak yang sama pada seutas kawat, baik kawat itu dalam keadaan lurus maupun dibengkokbengkokkan.

c. Konservasi kuantitas kontinyu atau kuantitas zat cair, pada saat anak rata-rata berusia sekitar 6-7 tahun; "Jumlah suatu zat cair dalam suatu bejana adalah tetap meskipun dipindahkan ke bejana-bejana lain yang berlainan ukuran"

d. Konservasi substansi atau kuantitas zat padat, pada saat anak rata-rata berusia sekitar 6 - 7 tahun; "Banyaknya zat suatu obyek akan tetap sama meskipun bentuknya diubah". Sebungkus kerupuk tidak akan bertambah atau berkurang banyaknya meskipun dihancurkan. Sebuah mangga tidak akan bertambah banyak meskipun diiris kecil-kecil.

e. Konservasi luas, pada saat anak rata-rata berusia lebih dari 7 tahun; "Luas suatu obyek yang ditutup dengan suatu bangun geometris, akan tetap sama dengan cara bagaimanapun menutupnya". Luas beberapa petak yang tertutup oleh sejumlah kartu remi akan tetap sama meskipun cara menutupnya berbeda-beda f. Konservasi berat, pada saat anak rata-rata berusia sekitar 9 - 12 tahun; "Berat suatu obyek di suatu tempat adalah tetap meskipun bentuknya berubah". Berat planit bumi adalah tetap meskipun bentuknya dari zaman ke zaman berubah.

g. Konservasi volume, pada saat anak rata-rata berusia sekitar 11 - 12 tahun lebih. "Volume 
suatu zat akan tetap sama meskipun wadah yang ditempatinya berubah"

Dari pemaparan diatas pada anak usia sebelum 7 tahun masuk dalam tahapan konservasi. Dari tahapan tersebut anak usia sebelum 7 tahun bisa dilakukan pengukuran kemampuan konservasi pada konservasi jumlah, panjang, cair, dan massa. Tahapan pada perkembangan ini bisa saja tidak dapat dilakukan oleh anak usia sebelum 7 tahun, tergantung lingkungan dan pengalaman yang dimilikinya.

\section{METODE}

Penelitian ini menggunakan metode penelitian Desain Based Research atau penelitian berbasis desain atau rancangan dengan pendekatan kualitatif pada pendekatan kualitatif mengandalkan data berupa teks dan gambar, memiliki langkah analisis data yang unik dan penjabaran desain yang beragam. Easterday, M.W. (tt, hlm 3) menjelaskan "desain based research merupakan proses penelitian yang mengintegrasikan desain dan metode ilmiah yang dapat digunakan oleh peneliti unuk menghasilkan produk yang berguna dan teori yang efektif untuk mnyelesaikan permasalahan individu dan kelompok dalam pendidikan."

Lebih jauh, Reeves dalam Arthur Bakker and Dolly van Erde (2015, Hlm. 430) juga menjelaskan bahwa, "DBR thus produces both useful product (e.g., educational materials) and acommpanying scientific insights into how these products can be used in education". Yakni bahwa DBR adalah penelitian yang menghasilkan suatu produk yang bermanfaat (misalnya materi pendidikan) dan menghubungkan pemikiran saintifik pada bagaimana produk tersebut dapat bermanfaat bagi pendidikan.

Dari pernyataan tersebut dengan demikian peneliti memandang bahwa penelitian ini cocok menggunakan penelitian DBR karna penelitian ini menghasilkan suatu produk berupa buku panduan sebagai pedoman alat ukut untuk mengukur berpikir konservasi anak usia 5-6 tahun. Dengan begitu peneliti akan merancang, mengembangkan dan menguji kelayakan produk untuk mengukur berpikir konservasi anak usia 5-6 tahun.

Lokasi yang digunakan sebagai bahan untuk mengumpulkan data yaitu di ruang guru RA Al-Hikmah Kecamatan Bungursari Kelurahan Sukamulya dan rumah dari subjek penelitian yaitu di Kp. Negla Kecamatan Cibeureum Kota Tasikmalaya. Pemilihan lokasi penelitian dilakukan berdasarkan pada pertimbangan untuk mengukur kemampuan berpikir konservasi yang bisa dilakukan dimana saja, namun penelitiannya dilakukan di ruangan yang hanya peneliti dan 1 subjek peneliti yang akan diukur kemampuannya tampa ada subjek peneliti lain yang melihatnya.

Subjek dalam penelitian ini adalah anak yang berusia 5-6 tahun yang akan memasuki jenjang sekolah dasar sebanyak 5 orang anak yang terdiri dari 4 orang anak yang terdiri dari 2 anak perumpuan dan 2 anak laki-laki dari RA Al-Hikmah Kecamatan Bungursari Kelurahan Sukamulya Kota Tasikmalaya, dan 1 orang anak perempuan dari TK Ceria Kp. Negla Kecamatan Cibeureum. Teknik pengambilan sampel dalam penelitian ini adalah Purposive Sampling, yaitu teknik pengambilan sampel sumber data dengan pertimbangan tertentu (dalam Sugiyono, 2013, hlm 300). Pengambilan sampel dalam penelitian ini tidak diambil secara random, hal ini dikarenakan menurut Lincoln dan Guba (1985) dalam Sugiyono (2013, hlm. 301) mengemukakan bahwa, "penentuan sampel dalam penelitian kualitatif (naturalistik) sangat berbeda dengan penentuan sampel dalam penelitian konvensional (kauntitatif). Penentuan sampel dalam penelitian kualitatif tidak didasarkan perhitungan statistik".

Prosedur dalam penelitian ini menggunakan model Reeves (dalam Plomp,2007, hlm.14) langkah nya adalah sebagai berikut :

1. Identifikasi dan analisis masalah oleh peneliti dan praktisi secara kolaboratif

Peneliti melakukan identifikasi dan analisis masalah terhadap teori piaget dan mengamati kejadian dilapangan lalu peneliti mengembangkan media yang dipakai oleh 
piaget untuk mengukur perkembangan berpikir konservasi anak usia 5-6 tahun

2. Mengembangkan prototype solusi yang didasarkan pada patokan teori, design principle yang ada dan inovasi teknologi

Peneliti merancang pengembangan instrumen berupa buku panduan sebagai pedoman alat ukur untuk mengukur berpikir konservasi pada teori piaget. Dalam pengembangannya dikonsultasikan dengan dosen untuk mengukur kesesuaian dalam pengembangan instrumennya. Pengembangan instrumen ini dibuat untuk dapat mengukur kemampuan anak usia dini dan juga membantu orangtua/guru untuk dapat mengukur berpikir konservasi anak usia dini dengan menggunakan buku panduan yang dibuat

3. Melakukan proses berulang untuk menguji dan memperbaiki solusi secara praktis

Setelah rancangan dari produk dibuat, kemudian peneliti melakukan proses berulang untuk ujicoba penerapan produk untuk melihat kesesuaian produk dalam mengukur berpikir konservasi anak usia 5-6 tahun. Kemudian produk ditinjau oleh para ahli (dosen) untuk di validasi. Selanjutnya dilakukan perbaikan dari solusi tersebut secara praktis dan dilakukan uji coba yang kedua

4. Refleksi untuk menghasilkan design principle serta meningkatkan implementasi dari solusi secara praktis.

Peninjauan terhadap kumpulan data terkait produk dari lapangan dan perbaikan dari para ahli. Peninjauan ini adalah prosedur akhir untuk memodifikasi kekurangan-kekurangan dengan kata lain dilakukan refleksi terhadap produk yang telah di revisi. Jika masih ada kekurangan maka di revisi kembali hingga layak dan sesuai dengan yang diharapkan. Begitulah seterusnya proses penelitian untuk meminimalisir kekurangan agar menghasilkan produk akhir yang sesuai dan layak digunakan. Dalam penelitian ini, ujicoba dilakukan sebanyak 2 kali. Sehingga proses refleksi dilakukan melalui analisis data secara keseluruhan setelah pelaksanaan percobaan kedua dan revisi akhir.

Devinisi operasional dalam hal ini merupakan penjabaran dari variabel penelitian. Menurut
Arikunto (2013, hlm. 159) "variabel adalah objek penelitian yang bervariasi".

\subsubsection{Berpikir Konservasi}

Desmita (2006) konservasi yaitu kemampuan untuk memahami sifat-sifat atau aspek-aspek tertentu dari suatu objek atau stimulus tetapi tidak berubah ketika aspek aspek lain mengalami perubahan. Dr. Yuliani Nurani (2013:80) konservasi digambarkan sebagai pengetahuan mengenai nomor, jumlah, massa, panjang, berat, dan volume dari objek yang tidak berubah apabila secara fisik. Dari dua pengertian tersebut dapat disimpulkan bahwa konservasi berkenaan dengan pengertian, bahwa sifat-sifat suatu objek tetap sama meskipun terjadi transformasitransformasi pada objek tersebut.

\subsubsection{Anak Usia 5-6 tahun}

Peraturan Menteri Pendidikan dan kebudayaan Republik Indonesia Nomor 137 Tahun 2014 lampiran 1 tentang Standar Isi Tingkat Pencapaian Perkembangan Anak untuk anak usia 5-6 tahun dalam lingkup perkembangan kognitif (berpikir logis), sebagai berikut:

1. Mengenal perbedaan berdasarkan ukuran: "lebih dari"; "kurang dari"; dan "paling/ter".

2. Menunjukkan inisiatif dalam memilih tema permainan (seperti: "ayo kita bermain purapura seperti burung").

3. Menyusun perencanaan kegiatan yang akan dilakukan.

4. Mengenal sebab-akibat tentang lingkungannya (angin bertiup menyebabkan daun bergerak, air dapat menyebabkan sesuatu menjadi basah).

5. Mengklasifikasikan benda berdasarkan warna, bentuk, dan ukuran (3 variasi).

6. Mengklasifikasikan benda yang lebih banyak ke dalam kelompok yang sama atau kelompok yang sejenis, atau kelompokberpasangan yang lebih dari 2 variasi.

7. Mengenal pola ABCD-ABCD.

8. Mengurutkan benda berdasarkan ukuran dari paling kecil ke paling besar atau sebaliknya. 


\section{HASIL DAN PEMBAHASAN}

4.2.1 Pengembangan instrumen untuk mengukur berpikir konservasi anak usia 5-6 tahun

Peneliti pada tahap ini menganalisis berdasarkan hasil teori piaget tentang berpikir konservasi, peneliti tertarik dengan percobaan yang dilakukan oleh piaget dalam mengukur kemampuan berpikir konservasi. Dan juga hasil analisis dilapangan peneliti menemukan bahwa belum adanya pengembangan untuk mengukur berpikir konservasi anak usia 5-6 tahun. Dari teori piaget anak pada usia 5-6 tahun sudah mulai diberikan pemahamanpemahaman mengenai konservasi dari orangtua/gurunya. Dikutip dalam buku Carin \& Sund, 1989: 34 terdapat kalimat "karena berpikir konservasi ini dilakukan agar anak siap memasuki jenjang sekolah dasar juga agar anak cakap dalam belajar untuk kedepannya".

Berdasarkan hasil pemahaman tersebut peneliti merancang suatu produk untuk mengukur berpikir konservasi anak usia 5-6 tahun berupa buku panduan sebagai pedoman alat ukur

4.2.2 Proses Pengembangan instrumen untuk mengukur berpikir konservasi

Peneliti, pada tahap rancangan desain produk ini melakukan analisis terhadap berpikir konservasi itu sendiri untuk mengimplementasikan pada pembelajaran yaitu berupa prinsip atau karakteristik berpikir konservasi, deskripsi dari prinsip atau karakteristiknya, implementasi pada pembelajaran, fasilitas pendukung dalam implementasi pembelajaran, dan keterangan tempat atau waktu dilakukannya. Pengembangan rancangan instrumen ini dilakukan agar nantinya produk berupa buku panduan dapat layak digunakan.

Setelah melalui tahap pembuatan produk, peneliti melakukan validasi produk oleh para ahli. Ahli ini merupakan ahli pada bidangnya di lingkungan UPI Kampus Tasikmalaya. Berdasarkan validasi oleh para ahli, hasilnya yaitu produk pengembangan instrumen untuk mengukur berpikir konservasi anak usia 5-6 tahun layak dipakaidengan revisi sesuai saran. Hasil dari revisi sesuai saran validator, peneliti kemudian menguji cobakannya ke anak usia 56 tahun.

4.2.3 Proses Uji Coba pengembangan instrumen untuk mengukur berpikir konservasi anak usia 5-6 tahun

Dalam proses uji coba, penelitian ini dilakukan dua kali dan mendapatkan revisi sebanyak 2 kali. Untuk subjek penelitiannya yaitu anak usia 5-6 tahun sebanyak 5 orang. Untuk uji coba 1 dilakukan uji coba pada satu anak dan dilaksanakan dirumah subjek penelitian yaitu di kp. Negla , untuk uji coba kedua dilakukan di RA Al-Hikmah sebanyak 4 orang anak. Untuk uji coba 1 dan 2 dijelaskan dibawah ini.

4.2.4 Refleksi produk merupakan menghasilkan produk akhir yakni pengembangan instrumen untuk mengukur berpikir konservasi anak usia 5-6 tahun berupa buku panduan berpikir konservasi sebagai pedoman alat ukur. Peneliti membuat suatu produk untuk dilakukan oleh guru/orangtua untuk mengukur berpikir konservasi pada anak usia 5-6 tahun.

Didalam buku panduan ini terdapat alat dan bahan, serta cara menggunakan. Adapun tujuan pengembangan ini yaitu untuk mengetahui dan mengukur berpikir konservasi anak usia 5-6 tahun, karena rata-rata banyak yang kurang menguji anak untuk mengetahui berpikir konservasinya sampai dimana. Dan banyak yang kurang mengetahui cara untuk mengukur berpikir konservasinya. Maka dari itu dibuatkan buku panduan supaya guru dapat mencoba mengukur berpikir konservasi anak.

\section{KESIMPULAN}

Berdasarkan hasil penelitian yang telah dilakukan pada umur 5-6 tahun dalam kemampuan berpikir konservasi maka peneliti dapat menyimpulkan bahwa :

1. Kenyataan dilapangan tidak sedikit pendidik yang kebanyakan tidak mengukur berpikir konservasi pada anak usia 5-6 tahun

2. Agar perkembangan berpikir konservasi anak dapat diketahui, maka dilakukanlah rancangan pengembangan instrumen berupa buku panduan untuk pedoman alat ukur untuk mengukur berpikir konservasi anak. Dalam tahap desain ini dihasilkan rancangan 
pengembangan instrumen berupa buku panduan untuk pendidik dengan menggunakan karakteristik dari konservasi, setelah desain pengembangan instrumen berupa buku panduan telah selesai dirancang, maka dilakukan penilaian validasi ahli untuk mengetahui kevalidan dari produk agar dapat diujicobakan. Setelah dilakukan beberapa revisi atau perbaikan berupa saran dan komentar dari ahli maka pengembangan instrumen untuk mengukur berpikir konservasi anak usia 5-6 tahun siap diujicobakan.

3. Proses uji coba ini dilakukan sebanyak dua kali. Berdasarkan hasil uji coba 1, peneliti dapat mengukur kemampuan berpikir konservasi, namun peneliti tidak menanyakan jawaban dari subjek yang diteliti sehingga dilakukanlah revisi. Pada uji coba kedua peneliti mendapatkan hasil dari pemahaman berpikir konservasi pada setiap anak. Juga peneliti mendapatkan jawaban dari alasan anak tentang jawabannya. Setelah uji coba kedua tidak ada revisi karena validator mengatakan bahwa peneliti sudah berhasil mengukur berpikir konservasi anak, selanjutnya untuk produk akhirnya berupa buku panduan sebagai pedoman untuk mengukur berpikir konservasi anak usia 5-6 tahun

4. Setelah melakukan tahap uji coba sebanyak dua kali dan revisi sebanyak dua kali, maka hasil dari penelitian ini berupa buku panduan berpikir konservasi anak usia 5-6 tahun yang didalamnya berisi panduan-panduan guru untuk mengukur berpikir konservasi anak usia 5-6 tahun

\section{SARAN}

1. Masyarakat yang dalam hal ini orangtua, agar senangtiasa memahami tentang pentingnya berpikir konservasi anak usia 5-6 tahun yang akan memasuki jenjang sekolah dasar ebagai kesiapan memasuki pendidikan dasar juga cakap dalam belajar.

2. Guru-Guru PAUD agar dapat senantiasa memperhatikan perkembangan berpikir konservasi anak dan melakukan pengukuran terhadap perkembangan berpikir konservasinya 3. Orangtua anak usia dini, dapat menjadikan hasil penelitian ini sebagai masukan dalam mengembangkan berpikir konservasi yang disesuaikan dalam tahap usia anak

4. Peneliti selanjutnya agar melakukan pengembangan melalui penelitian yang lebih luas terkait berpikir konservasi anak usia 5-6 tahun

\section{DAFTAR PUSTAKA}

Arikunto, S. (2013). Prosedur Penelitian. Jakarta: Rineka Cipta.

Arthur ,Carin. \& Sund, B. (1989). Teaching Science Throught Discovery. Colombus, Ohio: Merril Publishing Company

Desmita (2013). Psikologi Perkembangan. Bandung: Rosda.

E. Labinowicz. (1980). The Piaget Primer: Thinking, learning, teaching. Menlo Park, CA: Addison-Wesley.

Eerde, A. B. (2015). An Introduction to Design-Based Research with an Example From Statistics Education. Approaches to Qualitative Research in Mathematics Education, Chapter 16. Netherlands: Springer Science+Business Media Dordrecht,.

El-Khuluqo, Ihsana. 2015. Manajemen PAUD Pendidikan Anak Usia Dini. Yogyakarta: Pustaka Pelajar.

Holis, A. 2017. Belajar Melalui Bermain untuk Pengembangan Kreativitas dan Kognitif Anak Usia Dini. Jurnal: Pendidikan UNIGA. Journal.uniga.ac.id.

Jan van Den Akker, K. G. (2006). Educational Design Research. USA and Canada: Routledge.

Kennedy-Clark, S. (2013). Research by Design: Design-Based Research and the Higher Degree Research Student. Journal of Learning Design. Vol. 6 No.2.

Kemendikbud. 2014. Peraturan Menteri Pendidikan dan Kebudayaan Republik Indonesia Nomor 137 Tentang Standar Nasional Pendidikan Anak Usia Dini. 
Jakarta: Kementerian Pendidikan dan Kebudayaan.

Kemendikbud. 2014. Peraturan Menteri Pendidikan dan Kebudayaan Republik Indonesia Nomor 137 Tentang Standar Nasional Pendidikan Anak Usia Dini. Jakarta: Kementerian Pendidikan dan Kebudayaan.

Kemendikbud. 2014. Peraturan Menteri Pendidikan dan Kebudayaan Republik Indonesia Nomor 146 Tentang Kurikulum 2013 Pendidikan Anak Usia Dini. Jakarta: Kementerian Pendidikan dan Kebudayaan.

Lidinillah, D. A.M. (2012). Educational Design Research : a theoretical Framework for Action. Tasikmalaya: Universitas Pendidikan Indonesia Kampus Tasikmalaya.

Mukhlisah, AM. 2015. Pengembangan Kognitif Jean Piaget Dan Peningkatan Pembelajaran. Jurnal: kependidikan islam. Jurnalki.uinsby.ac.id.

Olivia, Stella. (2015). Deteksi Dini Psikologi Balita Hingga Manula. Jakarta: PT Elex Media Komputindo Kelompok Media.

Santrock, J.W. (2007). Perkembangan Anak. Jakarta: Erlangga.

Suardiman, Siti. (2003). Psikologi Perkembangan. Yogyakarta: (S.1.)

Sugiyono, (2013). Metode Penelitian Pendidikan. Bandung: Alfabeta.

Sujiono, Yuliani Nurani (2013). Konsep dasar pendidikan anak usia dini. Jakarta: Indeks.

Sukardi. (2010). Metodologi Penelitian Pendidikan. Jakarta: PT Bumi Aksara.
Watanabe, N. Conservation Concept Of Numbers, Lengths, and Liquids As Ordinary Play. Journal : Journal Of Educational and Developmental Psychology, $\quad 7, \quad$ 1. Doi: http://doi.org/10.5539/jedp.v7n1p210.

Widiyati, W. 2016. Belajar dan Pembelajaran Perspektif Teori Kognitivisme. Jurnal: biology science and education. Ejurnal.lp2miainambon.id

Yuliani NS, et. Al. (2004). Metode Pengembangan Kognitif. Jakarta: Penerbit Universitas Terbuka.

Yusuf, S (2008). Psikologi Perkembangan Anak dan Remaja. Bandung: Remaja Rosdakarya 